\title{
KAJIAN KELOMPOK RISIKO TINGGI: STUDI PENDAHULUAN PENGEMBANGAN MODEL PENGENDALI PREVALENSI PENYAKIT KARDIOVASKULAR
}

\author{
Wiwit Nurwidyaningtyas ${ }^{1 *}$, Siti Kholifah ${ }^{1}$, Aditya Rahma ${ }^{1}$ \\ 1. Program Studi S1 Keperawatan, STIKes Kendedes Malang, Jawa Timur 65126, Indonesia \\ *Email: wiwit_nurwidyaningtyas@yahoo.com
}

\begin{abstract}
Abstrak
Peningkatan kasus penyakit kardiovaskular (PKV)baik pada kelompok penyakit jantung koroner atau Cerebrovascular Attack (CVA) perlu mendapat perhatian mengingat kecenderungan pergeseran usia serangan. Tindakan pencegahan perlu dilakukan sedini mungkin. Penelitian deskriptif eksplorasi ini mengkaji kelompok risiko tinggi untuk dikategorikan derajat risikonya dengan Framingham Risk Score (FRS) 10 years. Kajian ini dilakukan pada 25 orang responden yang termasuk kelompok berisiko di Malang Raya.Terdapat 64\% yang termasuk dalam kategori risiko sangat rendah, 20\% risiko sedang, dan masing-masing $8 \%$ kategori risiko rendah dan tinggi mengalami serangan PKV dalam 10 tahun yang akan datang. Fakor risiko PKV hampir selalu melekat dengan gaya hidup masyarakat yang berlangsung lama, tidak disadari, dan sulit untuk diubah dan dikondisikan dengan belum terbiasanya istilah identifikasi kelompok risiko melalui FRS 10 Years. Penting dibentuk model kepemimpinan komunitas yang kuat dimasyarakat untuk mengidentifikasi faktor risiko, bekerjasama dengan tenaga kesehatan untuk melakukan manajemen faktor risiko, sehingga prevalensi PKVdapat ditekan. Hal ini akan berimplikasi pada penghematan biaya hospitalisasi akibat PKV.
\end{abstract}

Kata kunci: FRS 10 years, PKV, risiko tinggi PKV

\section{Abstract}

High Risk Group Study: a Preliminary Study for Developing Model for Controlling Cardiovascular Disease. The increasing cases of Cardiovascular Disease (CVD)both of coroner attack or Cerebrovascular Attack (CVA) needs more attention since there is a tendency the occurance of onset shift based on age, which are always based on lifestyle. This disease can be identified with Framingham Risk Score 10 years. The aim of this studywas to explore non healthy life style and to identify risk group categories with the FRS 10 yearsapproach. This research was conducted in a risk group of 25 respondents in Malang region selected using accidental sampling technique. $64 \%$ respondents of high risk group were categorized as very low risk of CVD onset tendency for the next 10 years; $20 \%$ respondents were in the medium category, whereas $8 \%$ of each was categorized in low and high risk category of CVD onset tendency for the next 10 years. CVD risk factors werein line with people's lifestyle in a long period. It was not recognized and it was hard to be changed. Yet, it was in line with unfamiliar phenomenon of risk group identification through FRS 10 years. Therefore it is important to build strong community leadership models in the community to identify the risk factors and together with health workers perform its management to prevent the prevalence of CVD risk factors so that the costs of hospitalization due to CVD can be reduced.

Keywords: CVD, FRS 10 years, The increasing cases of Cardiovascular Disease

\section{Pendahuluan}

Salah satu jenis kasus penyakit kardiovaskular (PKV) yaitu Penyakit jantung Koroner (PJK) aterosklerosis dari tahun ke tahun prevalensinya mengalami peningkatan, sehingga oleh WHO dinyatakan sebagai ancaman global. Diperkirakan 1,9 milyar manusia atau $1 / 3$ penduduk dunia mengalami penyakit ini (WHO, 2007). Penyakit kardiovaskuler adalah penyakit yang disebabkan oleh gangguan fungsi jantung dan pembuluh darah, seperti 
PJK, Gagal Jantung, atau Payah Jantung, Hipertensi, dan Stroke. Pada tahun 2008 diperkirakan sebanyak 17,3 juta kematian disebabkan oleh penyakit kardiovaskuler. Lebih dari tiga juta kematian tersebut terjadi sebelum usia 60 tahun dan seharusnya dapat dicegah. Kematian "dini" yang disebabkan oleh penyakit jantung terjadi berkisar $4 \%$ di negara berpenghasilan tinggi sampai dengan $42 \%$ terjadi di negara berpenghasilan rendah. Prevalensi penyakit jantung koroner di Indonesia tahun 2013 sebesar $0,5 \%$ atau diperkirakan sekitar 883.447 orang (Kemenkes, 2014). Etiologi yang umum ditemukan pada PKV ada atherosklerosis. Penyebab terjadinya atherosklerosis diantaranya dislipidemia, radikal bebas, dan disfungsi endotel (Rabelink, de Boer, \& van Zonneveld, 2010).

Segala bentuk PKV baik penyakit jantung koroner maupun stroke atau Cerebro-Vascular Attack (CVA) hampir selalu didasari oleh gaya hidup seperti merokok, kurangnya olah raga dan konsumsi makanan berlemak yang berlangsung dalam kurun waktu 10-15 tahun atau bahkan lebih (Kemenkes, 2014). Sekitar 59\% dari kelompok usia dewasa muda yang mengalami PJK atau penyakit yang sejenis mempunyai satu atau lebih faktor risiko berikut, yaitu riwayat keluarga mengalami PJK dini, merokok, hipertensi, atau obesitas (Kuklina, Yoon, \& Keenan, 2010).

Ketidaktahuan dan kebiasaan yang menahun dan turun menurun yang hampir dilakukan setiap hari tanpa diiringi dengan pembakaran kalori yang memadai melalui olah raga menjadi faktor utama peningkatan risiko gangguan vaskuler yang berdampak pada peningkatan prevalensi PKV di Indonesia. Adapun kebiasaan yang dimaksud dapat berupa perilaku merokok ataupun kebiasaan dalam bentuk penyajian makanan yang tidak sehat seperti terlalu sering mengkonsumsi makanan berbahan dasar santan untuk sayuran, lauk pauk yang digoreng, misalnya tahu, tempe, ayam, ikan, dan sebagainya, dan memberi garam dalam masakan dengan jumlah yang berlebihan (Nurwidyaningtyas, 2013).

Mengubah gaya hidup seseorang atau kelompok risiko tinggi tentunya bukanhal yang mudah. Perubahan perilaku hampir selalu berdasar pada pemahaman dan kesadaran tinggi individu yang seringkali berlawanan dengan kebiasaan sebelumnya yang sudah berlangsung lama. Kondisi ini mungkin menjadi hal yang tidak menyenangkan. Oleh karena itu, peran keluarga dan komunitas sangat penting dalam membentuk kebiasaan seseorang (Nurwidyaningtyas, Kholifah, Rahma, Rakhmawati, \& Febri, 2014).

PKV ini merupakan penyakit yang dapat dicegah. Upaya pencegahan terutama dilakukan pada kelompok berisiko di komunitas. Penentuan kelompok berisiko dapat dilakukan dengan berbagai macam instruman. Framingham Risk Score(FRS) 10 years merupakan salah satu alat yang yang paling sensitif untuk menentukan faktor risiko PKV dalam 10 tahun yang akan datang melalui pengkategorian risiko; mulai dari risiko sangat rendah, risiko rendah, risiko sedang sampai risiko tinggi (Scottish Intercollegiate Guidelines Network, 2007).Akan tetapi, menurut studi yang dilakukan oleh Nurwidyaningtyas (2013) alat ukur ini belum umum digunakan di masyarakat. Hal ini dapat terjadi karena masyarakat kurang memahami bahwa kelompok risiko tinggi PKV dapat diidentifikasi dengan cara yang dapat dilakukan baik oleh kader, warga atau justru keluarga inti sendiri. Deteksi dini kelompok risiko ini dapat menahan peningkatan prevalensi PKV.

Kondisi ini mengharuskan dilakukan penelitian yang bertujuan untuk mengkaji kelompok risiko tinggi untuk dikategorikan derajat risikonya beserta beberapa perilaku atau gaya hidup sehari-hari yang berisiko meningkatkan kecenderungan PKV dengan menggunakan FRS. Penelitian ini merupakan studi pendahuluan untuk mengembangkan model kepemimpinan di komunitas untuk 
mengendalikan peningkatan prevalensi penyakit kardiovaskular.

\section{Metode}

Rancangan penelitian yang digunakan adalah deskriptif eksplorasi melalui kajian terhadap faktor risiko dilakukan pada kelompok risiko. Penelitian ini melibatkan sejumlah 25 orang responden yang terdiri dari 12 orang perempuan dan 13 orang laki-laki diwilayah Malang Raya yang dipilih dengan menggunakan tehnik accidental sampling.

Adapun kriteria inklusi responden mencakupperokok, tekanan darah sistolik (Systolic Blood Pressure=SBP) masuk dalam kriteria pre-hipertensi Joint National Committee (JNC) 7, Lingkar perut di atas 90 $\mathrm{cm}$ bagi laki-laki dan lebih dari $80 \mathrm{~cm}$ bagi perempuan, menderita DM, dan Hiperkolesterolemia. Kriteria eksklusi yaitu pernah mengalami keluhan nyeri dada dan mempunyai riwayat pernah masuk rumah sakit (MRS) atas indikasi CVA atau PJK.

Kajian dilakukan terhadap parameter usia, gender, tekanan sistolik pada lengan kanan dan kiri, kebiasaan merokok, dan dilakukan puctie pembuluh darah perifer kemudian disentrifuge untuk diambil serum dan dilakukan analisis kadar High Density Lippoprotein (HDL) dan Total Cholesterol. Pengukuran dilakukan di Laboratorium Faal Fakultas Kedokteran Universitas Brawijaya Malang, dan hasil dari keseluruhan parameter diberikan poin sesuai dengan aplikasi Framingham Risk Score 10 Years dan dikategorikan menjadi; kelompok risiko sangat rendah jika total skor kurang dari 10, kelompok risiko rendah jika total skor kurang dari 15 , kelompok risiko sedang jika skor total antara 15-20, dan kelompok risiko tinggi jika skor total lebih dari 20.

Penelitian ini juga melakukan prosedur pelatihan untuk kader. Pelatihan ini dihadiri oleh 21 orang kader yang mewakili 21 wilayah RW yang masuk dalam wilayah kerja Puskesmas (PKM) Rampal Celaket. Mengi- ngat belum dibentuk suatu kader untuk kasus penyakit tidak menular maka kader yang dijadikan responden adalah kader lansia tetapi bukan kader balita. Pelatihan yang dimaksud terdiri daripemberian materi mengenai konsep PKV dan faktor risiko serta cara-cara pengendalian faktor risiko melalui identifikasi kelompok risiko tinggi dengan aplikasi Framingham Risk Score 10 years selama dua kali pertemuan. Selanjutnya dilakukan pre dan post test, dan diakhiri dengan aplikasi Framingham Studi pada pertemuan ketigauntuk menentukan kategori risiko responden kelompok II. Kegiatan dilakukan kurang lebih selama tiga bulan.

Aplikasi yang dimaksud untuk melakukan penskoringan FRS 10 years pada responden kelompok resiko yang ada diwilayah kerja kader masing-masing RW yang meliputi wilayah Kelurahan Samaan, Kelurahan Klojen dan Kelurahan Rampal Celaket. Kader dilatih untuk melakukan penskoringan terhadap parameter umur, jenis kelamin, tekanan darah, kebiasaan merokok, hasil pemeriksaan kadar kolesterol dan HDL melalui pengambilan darah tepi respondenoleh peneliti untuk dilakukan analisis dilaboratorium faal Universitas Brawijaya. Semua hasil pemeriksaan diberikan kepada kader untuk penentuan poin dalam lembar analisis FRS 10 years yang dibuat peneliti dan kemudian dievaluasi kemampuan kader dalam proses skoring kelompok resiko.

Penelitian ini dilakukan atas dasar prinsip etik penelitian. Persetujuan etik diperoleh dari institusi tempat peneliti utama berasal.

\section{Hasil}

Hasil penelitian pada Tabel 1 menunjukkan bahwa ada perbedaan rata-rata nilai responden kelompok I atau kader sebelum dan sesudah diberikan pelatihan melalui analisis Wilcoxon test $(\mathrm{p}=0,001 ; \alpha=0,05)$. Data ini menunjukkan bahwa setelah dilatih, para kader mempunyai pemahaman tentang PKV dan 
penggunaan FRS lebih baik dibanding sebelum dilatih.

Tabel 1. Perbedaan Nilai Rata-Rata Test pada Pelatihan Kader Sebelum dan Sesudah Diberikan Pelatihan

\begin{tabular}{lc}
\hline Test $_{\text {Statistics }}{ }^{a}$ & Sesudah - Sebelum \\
\hline $\mathrm{Z}$ & $-3,404^{\mathrm{b}}$ \\
Asymp. Sig. (2-tailed) & 0,001 \\
a. Wilcoxon Signed Ranks Test & \\
b. Based on negative ranks & \\
\hline
\end{tabular}

Tabel 2. Kategori Kelompok Risiko Berdasarkan FRS 10 Years

\begin{tabular}{lcc}
\hline \multicolumn{1}{c}{ Kategori } & Jumlah & Prosentase \\
\hline Risiko Sangat Rendah & 16 & $64 \%$ \\
Risiko Rendah & 2 & $8 \%$ \\
Risiko Sedang & 5 & $20 \%$ \\
Risiko Tinggi & 2 & $8 \%$ \\
\hline
\end{tabular}

Tabel 2 menunjukkan bahwa lebih dari setengah (64\%) kelompok responden II atau masyarakat masuk dalam kategori risiko sangat rendah terhadap kecenderungan terjadinya PKV dalam 10 tahun yang akan datang, 20\% responden termasuk dalam kategori risiko sedang dan masing-masing $8 \%$ masuk dalam kategori risiko rendah dan risiko tinggi.

Tabel 3. Faktor Risiko terhadap Penentuan Kategori FRS 10 years

\begin{tabular}{lcc}
\hline \multicolumn{1}{c}{ Variabel } & p & Korelasi \\
\hline gender -FRS & 0,000 & 0,665 \\
BMI - FRS & 0,701 & 0,064 \\
SBP - Chol. & 0,018 & 0,471 \\
gender - HDL & 0,000 & $-0,720$ \\
rerata SBP & & $136 \mathrm{mmHg}$ \\
rerata total Chol. & & $205 \mathrm{mg} / \mathrm{dl}$ \\
rerata HDL & & $49,4 \mathrm{mg} / \mathrm{dl}$ \\
\hline
\end{tabular}

Tabel 3 menunjukkan hasil bahwa sebesar $100 \%$ responden perempuan masuk dalam kategori risiko sangat rendah, sedangkan responden laki-laki hampir ada dalam semua rentang risiko mulai dari risiko sangat rendah sampai dengan risiko tinggi. Hal ini menunjukkan adanya hubungan antara jenis kelamin dengan kategori skoring menurut FRS 10 years $(\mathrm{p}=0,000 ; \alpha=0,05)$.
Faktor risiko yang perlu diwaspadai pada kelompok pengamatan II adalah $100 \%$ responden mengkonsumsi makanan gorengan tiap hari dan penggunaan garam yang berlebihan dalam masakan, rerata SBP 132 mmHg (pre-hypertension, JNC 7), ada hubungan signifikan antara SBP dengan FRS 10 years $(\mathrm{p}=0,018 ; \alpha=0,05)$. Sebanyak $68 \%$ responden mengkonsumsi makanan berkuah santan yang disebut blendrang dan rerata lingkar perut keseluruhan responden adalah 95 $\mathrm{cm}$ (lebih dari normal baik laki-laki atau perempuan), $84 \%$ responden masuk dalam kategori obese menurut WHO Asian BMI. Tidak terdapat hubungan signifikan antara BMI dengan FRS 10 Years $(\mathrm{p}=0,701 ; \alpha=$ $0,05)$. Hal ini berkaitan dengan parameter yang paling penting dalam FRS yaitu kadar total kolesterol dan kolerterol HDL bukan pada lingkar perut, berat badan ataupun tinggi badan.

Semua kader belum pernah mengetahui FRS 10 Years, tetapi kemampuan dalam melakukan skoring masih masuk dalam kategori cukup baik. Sembilan puluh persenresponden kelompok I dianggap tidak kompeten untuk melakukan tindakan promotif dan preventif oleh masyarakat, mengingat belum adanya standarisasi level pendidikan atau kemampuan kader. Peran kader saat ini hanya sebatas pada pelaksana harian posyandu dan belum terlatih untuk melakukan upaya promotif dan preventif.

\section{Pembahasan}

Aterosklerosis merupakan kondisi patologis yang mendasari terjadinya manifestasi kasus PKV di masyarakat. Meskipun proses penuaan pembuluh darah ini merupakan hal fisiologis terjadi berkaitan dengan proses penuaan, namun percepatan kekakuan pembuluh darah atau yang disebut dengan aterosklerosis bisa dikaitkan dengan gaya hidup manusia itu sendiri (Napoli, et al., 2006).

Gaya hidup yang kurang mendukung kesehatan, yaitu yang berkaitan dengan 
konsumsi makanan dan aktifitas fisik dapat meningkatkan faktor resiko PKV. Mengkonsumsi makanan tidak sehat misalnya, makanan tingi lemak yang berlebihan, kurang konsumsi makanan berserat, merokok, ngemil, mengkonsumsi gorengan, sayur bersantan, dan sebagainya. Aktifitas fisik yaitu kurang atau tidak rutin olahraga (George \& Johnson, 2010).

Gaya hidup seperti ini terbentuk melalui sebuah kebiasaan yang berlangsung secara terus menerus dalam waktu yang lama yang didukung oleh adanya suatu komunitas. Keluarga adalah komunitas terkecil dan termudah untuk membentuk suatu kebiasaan. Untuk merubahnya dibutuhkan sosok yang mampu mengatur dan memotivasi perubahan gaya hidup. Kader yang ada diwilayah kerja masing-masing perlu memahami tentang PKV dan faktor resikonya, sehingga dapat mengembangkan program yang secara rutin dilakukan untuk meningkatkan kesadaran tentang faktor resiko PKV dimasyarakat. Seorang kader perlu memiliki kekuatan atau pengaruhyang mampu merubah kebiasaan keluarga dari gaya hidup yang berisiko menjadi gaya hidup yang lebih sehat untuk menyelamatkan keluarga dari bahaya penyakit ini (Nurwidyaningtyas, et al., 2014).

Besarnya biaya yang harus dikeluarkan untuk pengobatan klien dengan masalah kardiovaskuler menjadi perhatian pada pengembangan upaya preventif yang lebih murah dan lebih efektif dalam menurunkan angka kesakitan dan kematian akibat PKV. Paparan faktor risiko penyakit kardiovaskuler mengakibatkan kerusakan fungsi pengaturan endothelium yang berkembang dari quiescent state to activation, apoptosis dan kematian sel endotel. Namun, belakangan ini ditemukan bahwa setengah dari pasien yang melaporkan manifestasi klinis PKV tidak memiliki salah satu faktor risiko (Sabatier, Camoin-Jau, Anfosso, Sampol, \& Dignat-George, 2008).

Berbagai parameter untuk memprediksi faktor risiko PKV seperti usia, gender, tekanan darah, kadar lipid darah, perokok dan diabetes melitus menjadi penting untuk penentuan derajat risiko PKV dengan menggunakan alat ukur FRS. FRS banyak menjelaskan kaitan risiko kardiovaskuler dengan PKV dalam 10 tahun ke depan yang dibagi menjadi 4 kategori kelompok risiko yaitu Risiko Sangat Rendah, low risk, moderate risk dan high risk yang mempunyai ketajaman $34,2 \%$ lebih besar dibandingkan dengan risk prediction models yang lain (Chia, 2011).

Responden kelompok risiko tinggi PKV berdasarkan analisis FRS dalam penelitian ini umumnya mempunyai faktor risiko kurang olahraga dan konsumsi makanan bersantan dan lauk-pauk yang selalu disajikan dengan cara menggoreng. Kebiasaan ini jika berlangsung lama dan menjadi kebiasaan akan meningkatkan HDL.

Nilai HDL yang masih dalam batas normal belum tentu diikuti oleh kadar kolesterol yang normal pula mengingat hampir keseluruhan responden perempuan mengalami hiperkolesterolemia. Pola makan tinggi lemak ini berdampak pada kejadian obesitas. Obesitas berhubungan dengan endotel dapat disebabkan oleh adanya efek yang memengaruhi keseimbangan ini (Golbidi, Mesdaghinia, \& Laher, 2012).

Penelitian ini menegaskan bahwa upaya pencegahan PKV dapat dilakukan sedini mungkin dengan melakukan deteksi di tingkat keluarga dan komunitas. FRS dapat diaplikasikan dengan mudah oleh kader. Penemuan kasus risiko tinggi PKV akan mencegah PKV atau penyakit kardiovaskuler lainnya.

\section{Kesimpulan}

Fakor risiko PKV hampir selalu melekat dengan gaya hidup masyarakat yang berlangsung lama, tidak disadari adanya dan sulit untuk diubah dan dikondisikan lagi dengan belum familiarnya istilah identifikasi kelompok risiko melalui FRS 10 Years. 
Penelitian ini menyimpulkan bahwa FRS 10 years ini dapat digunakan oleh kader dalam mendeteksi adanya kelompok berisiko tinggi mengalami PKV. Melalui pengambilan data dengan FRS didapatkan dua orang $(85 \%)$ berada pada kelompok risiko tinggi mengalami PKV dalam 10 tahun yang akan datang.

Hasil penelitian ini merekomendasikan pentingnya mengembangkan strong community leadership model ditengah masyarakat yang berkewajiban mengidentifikasi faktor risiko dan bersama dengan tenaga kesehatan unuk melakukan manajemen faktor risiko sehingga prevalensi PKV bisa ditekan dan selanjutnya dapat diturunkan, sehingga mampu memberikan dampak lanjutan berupa penekanan biaya hospitalisasi akibat PKV.

Model kepemimpinan dalam masyarakat ini mempunyai kualifikasi, sehingga mampu merubah gaya hidup masyarakat. Perubahan ini dapat dimulai pada lingkup wilayah Rukun Tetangga (RT) atau bahkan mulai dari suatu keluarga itu sendiri. Salah satu peran seorang kader adalah sebagai mitra tenaga kesehatan. Peran ini tidaklah mudah, sehingga diperlukan verifikasi kemampuan kader sebelum dilakukan penunjukan oleh pihak berwenang. Seorang kader yang baik juga mempunyai wibawa di hadapan masyarakat di wilayah kerjanya, sehingga diharapkan dapat melakukan perubahan perilaku masyarakat.

Alternatif lain untuk meningkatkan kemampuan kader adalah dengan melakukan seminar dan pelatihan terprogram yang disesuaikan dengan visi misi upaya promotif dan preventif dari pihak layanan kesehatan terkait (MR, AG, AR).

\section{Referensi}

AHA. (2013). Overweight \& obesity. American Heart Association \& American Stroke Association. Dallas, Texas: American Heart Association, Inc. Diperoleh dari http://www.heart.org.
Chia, Y.C. (2011). Review of tools of cardiovascular disease risk stratification: Interpretation, customisation and application in clinical practice. Singapore Med J, 52(2), 116123. Diperoleh dari http://www.ncbi.nlm.nih.gov/pubmed/2137373 8

George, S.J., \& Johnson, J. (2010).Atherosclerosis: Molecular and cellular mechanisms.Weinheim: WILEY-VCH Verlag $\mathrm{GmbH} \& \mathrm{Co.KgaA}$.

Golbidi, S., Mesdaghinia, A., \& Laher, I. (2012). Exercise in the metabolic syndrome. Oxidative medicine and cellular longevity, 2012, 1-13. doi: http://dx.doi.org/10.1155/2012/349710.

Kemenkes RI. (2014). Pusat data dan informasi Kementrian Kesehatan RI: Situasi kesehatan jantung. Jakarta: Kementerian Kesehatan RI.

Kuklina, E.V., Yoon, P.W., \& Keenan, N.L. (2010). Prevalence of coronary heart disease risk factors and screening for high cholesterol levels among young adults, United States, 1999-2006. Ann Fam Med, 8(4), 327-333. doi: 10.1370/afm.1137.

Napoli, C., Lerman, L.O., de Nigris, F., Gossl, M., Balestrieri, M.L., \& Lerman, A. (2006). Rethinking primary prevention of atherosclerosis-related diseases. Circulation, 114(23), 2517-2527. doi: 10.1161/CIRCULATIONAHA.105.570358

Nurwidyaningtyas. (2013).Rasio EPC dan CEC sebagai prediktor disfungsi endotel pada kelompok risiko tinggi berdasarkan FRS 10 years. Jurnal Kardiologi Indonesia, 34 (I), 14$19 . \quad$ Diperoleh dari http://webcache.googleusercontent.com/search ?q=cache:_WFApute2gJ:www.jki.ui.ac.id/ind ex.php/jki/article/view/369/0+\&cd=1\&hl=en $\&$ $\mathrm{ct}=\mathrm{clnk} \& \mathrm{client}=$ firefox $-\mathrm{b}$

Rabelink, T.J., de Boer, H.C., \& van Zonneveld, A.J. (2010). Endothelial activation and circulating markers of endothelial activation in kidney disease. Nat Rev Nephrol, 6 (7), 404414. doi: 10.1038/nrneph.2010.65. 
Sabatier, F., Camoin-Jau, L., Anfosso, F., Sampol, J., \& Dignat-George, F. (2008). Circulating endothelial cells, microparticles and progenitors: Key players towards the definition of vascular competence. J Cell Mol Med, 13(3), 454-471. doi: 10.1111/j.15824934.2008.00639.x.

Scottish Intercollegiate Guidelines Network. (2007). Risk estimation and the prevention of cardiovascular disease: A national clinical guideline. UK: NHS Quality Improvement Scotland. ISBN: 1899893997. Diperoleh dari http://www.sign.ac.uk/pdf /sign97.pdf
WHO. (2007). Prevention of cardiovascular disease: Guidelines for assessment and management of total cardiovascular risk. Switzerland: World Health Organization Press. ISBN: 9789241547178. Diperoleh dari http://ish-world.com.

Nurwidyaningtyas, W., Kholifah, S., Rahma, A., Rakhmawati, R., \&Febri, T.L. (2014). Let's be survivor cardio for our family from our family we can avoid cardiovascular disease. Jakarta: Nuansa Laras. ISBN: 978-602-70349-0-7. 